\title{
Pengaruh Knowledge Sharing terhadap Kinerja Karyawan Perusahaan Milik Pemerintah
}

\author{
Stephen Andreas Partogi* dan Sri Surjani Tjahjawati \\ Jurusan Administrasi Niaga, Politeknik Negeri Bandung, Indonesia
}

\begin{abstract}
:
Companies must be able to survive and compete in the midst of rapid changes that occur in the business world. There are many ways that companies can survive and compete with competitors, one of them is by developing the quality of human resource performance. There is one factor that affects the quality of employee performance in the company, whether positive or negative, the factor is knowledge sharing. Knowledge sharing itself is a sharing of knowledge, a step to provide an opportunity to members of a group, organization, agency, or company to share their knowledge with other members. Knowledge sharing applied by employees of a company will impact on the good performance of other employees in the company. This study aims to determine how much the relationship between knowledge sharing and employee performance. In this study, the object of research is a state-owned company engaged in the production and also buying and selling airplanes.
\end{abstract}

Keywords: knowledge sharing, employee performance, human resources management

\begin{abstract}
Abstrak:
Perusahaan harus mampu bertahan dan bersaing di tengah perubahan cepat yang terjadi di dunia bisnis. Ada banyak cara agar perusahaan dapat bertahan dan bersaing dengan pesaing, salah satunya adalah dengan mengembangkan kualitas kinerja sumber daya manusia. Ada satu faktor yang mempengaruhi kualitas kinerja karyawan di perusahaan, apakah positif atau negatif, faktornya adalah berbagi pengetahuan. Berbagi pengetahuan itu sendiri adalah berbagi pengetahuan, suatu langkah untuk memberikan kesempatan kepada anggota kelompok, organisasi, agensi, atau perusahaan untuk berbagi pengetahuan mereka dengan anggota lain. Berbagi pengetahuan yang diterapkan oleh karyawan suatu perusahaan akan berdampak pada kinerja karyawan lainnya yang baik di perusahaan. Penelitian ini bertujuan untuk mengetahui seberapa besar hubungan antara berbagi pengetahuan dan kinerja karyawan. Dalam penelitian ini, objek penelitian adalah perusahaan milik negara yang bergerak di bidang produksi dan juga membeli dan menjual pesawat terbang.
\end{abstract}

Kata kunci: berbagi pengetahuan, kinerja karyawan, manajemen sumber daya manusia

\section{Pendahuluan}

Seiring dengan berkembangnya perusahaan, dan semakin besar usaha yang dilakukan oleh perusahaan guna meningkatkan mutu sumber daya manusia dan kualitas kinerja karyawan, sebaiknya sumber daya manusia yang telah diterima sebagai karyawan mendapatkan bekal baik itu ilmu pengetahuan ataupun keahlian lainnya sesuai bidang yang ditekuni. Tetapi diluar dari itu semua, karyawan masih memerlukan proses pembelajaran dan juga penyesuaian dengan tugas dan pekerjaan 
yang akan diberikan oleh perusahaan. Karena ilmu pengetahuan dan keahlian atau keterampilan yang diperoleh dari lembaga pendidikan formal belum tentu selaras dan selalu sesuai dengan apa realita yang terjadi di lapangan kerja pada nantinya.

Knowledge sharing memiliki manfaat yang cukup besar bagi perusahaan jika dilaksanakan dan diterapkan dengan baik oleh karyawannya. Manfaatnya antara lain perusahaan mempunyai karyawan (khususnya karyawan baru di dalam perusahaan) yang siap melaksanakan pekerjaannya sehingga dengan terbentuknya tenaga kerja yang berkualitas, perusahaan dapat mencapai tujuan perusahaan dengan lebih mudah. Dengan diterapkannya knowledge sharing yang baik pada perusahaan, diharapkan karyawan akan dapat mempelajari dengan baik dan melaksanakan fungsinya dalam perusahaan. Selain itu, diharapkan pula adanya perkembangan sikap, attitude, pengetahuan dan juga kemampuan sumber daya manusia dalam perusahaan agar dapat membantu mencapai apa yang menjadi tujuan perusahaan. Knowledge sharing bagi karyawan merupakan sebuah proses atau langkah guna memberikan ruang kepada anggota suatu kelompok dalam perusahaan untuk membagikan pengetahuan dan informasi yang dimiliki kepada anggota lainnya. Dengan diterapkannya knowledge sharing dengan baik, akan dapat membantu perusahaan untuk mencapai tujuannya. Disamping itu, penerapan knowledge sharing bagi karyawan juga bermanfaat untuk mempererat hubungan antara karyawan, yaitu karyawan yang lebih senior dan memiliki pengalaman kerja yang lebih banyak dan juga lebih lama di perusahaan, dengan karyawan baru yang kemungkinan baru diterima di perusahaan dan masih memiliki sedikit pengalaman dan juga pengetahuan mengenai realita-realita yang terjadi di perusahaan tersebut.

Perbedaan jarak usia antara karyawan di perusahaan milik pemerintah seperti PT Dirgantara Indonesia yang cukup jauh menjadi permasalahan di dalam perusahaan. Hal ini dikarenakan keputusan perusahaan untuk menutup sementara perekrutan karyawan yang terhitung mulai dari masa kondisi kejatuhan PT Dirgantara Indonesia yang terjadi pada tahun 1998. Semenjak saat itu, PT Dirgantara Indonesia tidak pernah lagi membuka lowongan pekerjaan ataupun melakukan perekrutan karyawan baru, hingga akhirnya PT Dirgantara Indonesia membuka kembali perekrutan karyawan pada tahun 2012 silam. Karyawan-karyawan tersebut memiliki cakupan usia yang tergolong senior pada saat ini. Mengingat mereka sudah bekerja sebagai karyawan di PT Dirgantara Indonesia sejak sebelum masa-masa kondisi kejatuhan PT Dirgantara Indonesia pada 1998 silam.

Menurut Noor dan Salim (2011), terdapat dua faktor yang dapat mempengaruhi kemampuan di dalam knowledge sharing, faktor pertama adalah faktor teknis (teknologi), dan juga faktor non-teknis (mencakup faktor individu, budaya organisasi, dan juga struktur organisasi). Kedua faktor diatas juga dipengaruhi oleh pendidikan, pengalaman kerja, dan juga posisi di dalam organisasi. Berdasarkan hasil wawancara peneliti dengan pihak perusahaan, terdapat beberapa faktor yang mempengaruhi penerapan knowledge sharing pada perusahaan. Sejalan dengan teori diatas, jika dilihat dari faktor teknis (teknologi) diatas, karyawan baru dengan cakupan usia muda lebih menguasai dan memiliki kemampuan (skill) yang lebih di bidang teknologi dibandingkan dengan karyawan lama yang memiliki cakupan usia tua. Karyawan lama yang masih banyak memiliki sikap tidak mau belajar dengan perkembangan teknologi yang semakin pesat dan cenderung bersifat gengsi terhadap karyawan baru yang dianggap belum memiliki banyak pengalaman dalam dunia kerja. Hal-hal tersebutlah yang menyebabkan komunikasi antara karyawan kurang berjalan dengan efektif, sehingga berpengaruh pula terhadap kinerja karyawan di dalam perusahaan.

Berdasarkan wawancara peneliti di perusahaan pada Divisi Technology Center adalah bahwa akhir-akhir ini kinerja karyawan di PT Dirgantara Indonesia (Persero) khususnya pada bagian Engineering di Divisi Technology Center mengalami penurunan, hal ini dapat terlihat dari hasil pekerjaan yang belum sesuai dengan standar yang telah ditetapkan serta pelaksanaan pekerjaan yaitu pembuatan pesawat terbang yang tidak tepat waktu.

Tabel 1. Standar Waktu Penyelesaian

\begin{tabular}{|c|l|l|l|}
\hline No & \multicolumn{1}{|c|}{ Bagian } & \multicolumn{1}{|c|}{ Jangka Waktu Penyelesaian } & Real / Kenyataan \\
\hline 1 & Struktur Pesawat & 1 Bulan & 1 Bulan \\
\hline 2 & Elektrikal & 1 Bulan & 1,5 Bulan \\
\hline 3 & Avionik & 1 Bulan & 1 Bulan \\
\hline
\end{tabular}

Sumber : PT Dirgantara Indonesia (Persero) 
Dapat dilihat dari tabel 1 yang memperlihatkan standar waktu penyelesaian diatas, permasalahan yang terjadi adalah dari salah satu bagian yang dalam proses perangkaian pesawat terbang tersebut belum menyelesaikan pekerjaan tepat waktu. Hal ini dapat mengakibatkan penalty dan perusahaan harus membayar sejumlah penalty untuk hal tersebut dalam jumlah yang besar, serta di sisi lain dapat menyebabkan hubungan perusahaan dengan pelanggan tidak baik dan pesanan pesawat terbang pun tidak dapat terpenuhi tepat waktu.

\section{Kajian Literatur}

\subsection{Knowledge}

Knowledge atau pengetahuan yaitu faktor yang sangat penting bagi setiap karyawan dalam menjalankan setiap tugas dan pekerjaanya, karena jika setiap karyawan sudah menanamkan pengetahuan dalam dirinya masing-masing, maka karyawan tersebut dapat melakukan tugas dan pekerjaannya sesuai dengan yang diharapkan oleh perusahaan, sehingga nantinya dapat berdampak positif pada kinerja karyawan. Menurut Notoatmodjo (2010), pengetahuan adalah hasil penginderaan manusia, atau hasil tahu seseorang terhadap objek melalui indera yang dimilikinya (mata, hidung, telinga, dan sebagainya).

Notoatmodjo (2010) secara garis besar juga membagi pengetahuan ke dalam 6 tingkatan, yaitu:

1. Tahu (Know)

Tahu dapat diartikan sebagai mengingat suatu materi yang telah dipelajari sebelumnya. Tingkatan pengetahuan ini adalah mengingat kembali sesuatu yang spesifik dari seluruh materi yang telah dipelajari atau rangsangan yang telah diterima.

2. Memahami (Comprehention)

Memahami dapat diartikan sebagai suatu kemampuan untuk dapat menjelaskan secara benar tentang objek yang diketahui, dan dapat menginterpretasikan materi tersebut secara benar.

3. Aplikasi (Application)

Aplikasi dapat diartikan sebagai kemampuan untuk menggunakan materi yang sudah dipelajari pada situasi dan kondisi sebenarnya (real). Aplikasi disini dapat diartikan sebagai pengaplikasian atau penggunaan rumus, prinsip, metode, hukum-hukum, dan sebagainya dalam situasi atau konteks yang lain.

4. Analisis (Analysis)

Analisis merupakan kemampuan untuk dapat menjabarkan objek atau materi ke dalam komponenkomponen, tapi masih di dalam satu struktur, dan masih ada kaitannya satu dengan yang lain. Kemampuan analisis ini dapat dilihat bentuk nyatanya seperti dapat menggambarkan (membuat bagan), memisahkan, membedakan, mengelompokkan, dan sebagainya.

5. Sintesis (Synthesis)

Merujuk kepada kemampuan untuk dapat menghubungkan atau menempatkan bagian-bagian dalam suatu bentuk keseluruhan yang baru. Maka, dapat disimpulkan bahwa sintesis adalah suatu kemampuan untuk dapat menyusun formulasi baru dari formulasi-formulasi yang ada.

6. Evaluasi (Evaluation)

Evaluasi dalam arti kemampuan untuk dapat melakukan penilaian terhadap suatu objek atau materi. Penilaian-penilaian itu merujuk dari kriteria yang ditetapkan sendiri, atau berpedoman pada kriteriakriteria yang sudah ada.

\subsection{Kompetensi Individu}

Pengetahuan (knowledge) juga berkaitan dengan kompetensi yang dimiliki oleh setiap individu. Kompetensi akan sangat berpengaruh besar terhadap setiap individu, contohnya di dalam perusahaan, apabila karyawan memiliki kompetensi yang baik, tentunya perusahaan juga dapat terbantu dengan meningkatnya kinerja dari perusahaan. Menurut Simanjuntak (2011), kompetensi individu adalah kemampuan dan keterampilan melakukan kerja. Kompetensi individu dipengaruhi oleh beberapa faktor yang dikelompokkan menjadi dua golongan, yaitu:

1. Kemampuan dan keterampilan

a. Kebugaran fisik dan pendidikan jiwa

b. Pendidikan 

c. Pelatihan
d. Pengalaman kerja

2. Motivasi, sikap, dan etos kerja
a. Pandangan atas pekerjaan
b. Sikap melakukan pekerjaan
c. Sikap hidup produktif

\subsection{Knowledge Sharing}

Knowledge sharing menurut definisi Tobing (2011) merupakan suatu proses sistematis dalam mengirimkan, mendistribusikan, dan mendiseminasikan pengetahuan dan konteks multidimensi antar individu atau antar organisasi melalui metode atau media yang beragam. Aktivitas-aktivitas tersebut hubungannya dapat dikatakan erat seiring peningkatan kemampuan setiap individu untuk dapat berinovasi.Beberapa ukuran yang dapat dikatakan sebagai kemampuan atau kapabilitas untuk berinovasi yaitu kemampuan untuk dapat mengintegrasikan, mengadaptasikan, dan juga mengatur seluruh dari keahlian, kompetensi, serta sumber daya. Peran perusahaan di dalam menekankan penerapan knowledge sharing bagi karyawannya merupakan hal yang sangat penting, karena melalui proses penerapan knowledge sharing, pengetahuan dapat disebarkan, diimplementasikan, dan juga dikembangkan.

Penerapan knowledge sharing seiring dan sejalan dengan proses kinerja di perusahaan. Hal ini dibuktikan dengan pernyataan Azadehdel (2013), yaitu semakin baik penerapan knowledge sharing akan meningkatkan inovasi proses dan kualitas produk melalui penggunaan teknologi baru, maka kinerja perusahaan semakin meningkat. Maka dapat disimpulkan knowledge sharing merupakan proses membagikan dan mendistribusikan pengetahuan antara satu individu kepada individu yang lainnya yang dapat bermanfaat untuk merangsang setiap individu berpikir lebih kreatif dan efektif sehingga berdampak pada terciptanya peningkatan kinerja perusahaan.

Knowledge sharing juga dapat membantu karyawan untuk dapat menyelesaikan permasalahan yang terjadi dalam kegiatan pekerjaan sehari-hari. Tobing (2011) menyatakan bahwa melalui knowledge sharing akan terjadi eksploitasi maksimal dari suatu pengetahuan. Selain mengeksploitasi pengetahuan secara maksimal, knowledge sharing juga dapat membukakan kesempatan mengeksplorasi pengetahuan untuk mendapatkan atau menciptakan pengetahuan baru. Oleh sebab itu, penerapan budaya knowledge sharing yang baik antara karyawan sangat dibutuhkan, sehingga informasi seputar perkembangan dari dalam maupun luar lingkungan dapat disebarkan secara merata ke seluruh bagian dan tingkatan di dalam perusahaan.

\subsection{Kinerja Karyawan}

Kinerja karyawan adalah faktor yang penting dalam berbagai aspek pada perusahaan, seperti untuk meningkatkan produktivitas karyawan dan juga sekaligus meningkatkan produktivitas perusahaan. Wibowo (2011) menyatakan bahwa kinerja dianggap sebagai seberapa jauh karyawan dapat mewujudkan dan melaksanakan tugas yang telah dijabarkan sehingga menggambarkan pola perilaku dan kompetensi yang dimiliki karyawan tersebut. Adapun menurut Ruky (2010), kinerja merupakan suatu bentuk usaha kegiatan atau program yang diprakarsai dan dilaksanakan oleh pimpinan organisasi atau perusahaan untuk mengarahkan dan mengendalikan prestasi karyawan. Pendapat lain menurut Mangkunegara (2009) menyatakan bahwa kinerja merupakan hasil kerja secara kualitas dan kuantitas yang dicapai oleh seseorang pegawai dalam melaksanakan tugasnya sesuai dengan tanggung jawab yang diberikan kepadanya. Pernyataan serupa juga dikemukakan oleh Prawirosentono dalam Sinambela (2012) yaitu kinerja adalah hasil kerja yang dicapai oleh seseorang atau sekelompok orang dalam suatu organisasi, sesuai dengan wewenang dan tanggung jawab masing-masing, dalam rangka upaya mencapai tujuan organisasi bersangkutan secara legal, tidak melanggar hukum dan sesuai dengan moral dan etika. Maka dapat disimpulkan oleh peneliti bahwa kinerja karyawan adalah peruwujudan usaha kegiatan yang dilakukan oleh karyawan guna mengerjakan tugas dan pekerjaan yang diberikan oleh perusahaan, yang dilaksanakan dengan caracara dan ketentuan-ketentuan yang benar dan sejalan dengan moral dan etika.

Dalam upaya peningkatan kinerja karyawan, perusahaan harus bisa menganalisis faktor apa saja yang dapat mempengaruhi kinerja. Asegaff (2015) menyatakan bahwa kemampuan dalam melakukan 
inovasi yang diwujudkan dalam bentuk selalu mencoba ide-ide baru, mencoba metode operasi baru, inovasi produk, akan dapat meningkatkan kinerja. Faktor lainnya yang juga dapat mempengaruhi kinerja adalah knowledge sharing. Pernyataan tersebut seiring dengan pendapat Wening (2016) yang menyatakan bahwa meningkatnya aktivitas knowledge sharingakan berpengaruh pada meningkatnya kinerja individu. Pernyataan senada juga terdapat dalam Aulia (2016) yang menyatakan bahwa adanya hubungan positif antara knowledge sharing dan kinerja karyawan, selain itu knowledge sharing memiliki pengaruh yang signifikan terhadap kinerja karyawan.

\section{Metode Penelitian}

\subsection{Teknik Pengumpulan Data}

Guna mendapatkan hasil akhir penelitian yang baik, jelas, dan pastinya dapat dipertanggung jawabkan, maka metode penelitian yang digunakan dalam penelitian ini adalah metode kuantitatif. Menurut Sugiyono (2011), metode penelitian kuantitatif dapat diartikan sebagai metode penelitian yang berlandaskan pada filsafat positivisme digunakan untuk meneliti pada populasi atau sampel tertentu. Sedangkan teknik pengumpulan data yang digunakan adalah:

1. Wawancara

Metode mendapatkan informasi dengan cara mengajukan beberapa pertanyaan kepada narasumber secara lisan, serta mencatat informasi tersebut. Wawancara merupakan alat pembuktian terhadap informasi atau keterangan yang diperoleh sebelumnya.

2. Kuesioner

Suatu daftar yang di dalamnya mencakup beberapa pertanyaan atau pernyataan yang bertujuan untuk mengumpulkan data yang diperoleh dari responden yang dipilih.

3. Studi Pustaka

Selain mengumpulkan informasi dari wawancara dan menyebarkan kuesioner, metode lain untuk mendapatkan referensi dapat diperoleh dari buku, jurnal, penelitian sebelumnya, dan data online.

4. Pengolahan Data

Informasi yang didapatkan dari penyebaran kuesioner selanjutnya diolah menggunakan aplikasi IBM SPSS Statistic 20 untuk menghasilkan output guna memenuhi tujuan dari penelitian ini. Pengujian hipotesis dalam penelitian ini menggunakan analisis regresi sederhana dan uji $\mathrm{R}$ square.

\subsection{Teknik Analisis Data}

Uji validitas dilakukan untuk mengukur apakah alat ukur yang digunakan dalam penelitian sudah sesuai atau tidak.Ghozali (2011) mengatakan bahwa uji validitas digunakan untuk mengukur sah atau tidaknya suatu kuesioner. Kuesioner yang digunakan dapat dikatakan valid jika pertanyaan di dalam kuesioner mampu mengungkapkan suatu hal yang akan diukur pada kuesioner. Ketika suatu tes dapat menjalankan fungsinya atau dapat memberikan hasil yang tepat dan akurat, maka tes tersebut dapat dikatakan memiliki tingkat validitas yang tinggi.

Ghozali (2011) menyatakan bahwa reliabilitas merupakan alat ukur suatu kuesioner untuk indikator dari variabel.Suatu kuesioner dapat dikatakan reliabel jika pertanyaan yang terdapat di dalamnya dijawab dengan stabil atau konsisten oleh responden. Penulis menggunakan software SPSS karena mampu memfasilitasi untuk uji reliabilitas dengan uji Cronbach Alpha. Dapat dikatakan reliabel jika Cronbach Alpha $>0,70$.

Uji Asumsi Klasik merupakan suatu syarat yang harus dipenuhi dalam analisis regresi linier. Dalam uji asumsi klasik, digunakan dua uji yaitu uji normalitas dan uji linieralitas. Sunyoto (2010) menyatakan bahwa uji normalitas merupakan pengujian variabel bebas dan variabel terikat dengan persamaan regresi yang dihasilkan. Uji normalitas dilakukan dengan tujuan untuk mengetahui apakah data yang dimiliki akan mampu berdistribusi normal atau tidak.

Sugiyono (2013) menyatakan bahwa analisis deskriptif adalah analisis yang digunakan untuk menganalisa data dengan cara menggambarkan data yang telah terkumpul sebagaimana adanya tanpa bermaksud membuat kesimpulan bersifat general. Analisa ini bertujuan untuk mengetahui nilai rata - rata dari masing - masing indikator pada setiap variabel penelitian ini dan untuk memberikan gambaran mengenai indikator apa saja yang membangun konsep model penelitian secara keseluruhan. 
Sunyoto (2010) menyatakan bahwa analisis korelasi merupakan analisis statistik untuk mengukur tingkat hubungan antara variabel bebas dengan variabel terikat. Menurut Indrawati (2015), korelasi sederhana merupakan metode analisis statistik kuantitatif yang dimana peneliti melakukan pengujian terhadap dua variabel. Koefisien korelasi digambarkan dengan simbol "r" yang dimana besarnya $1<r \leq 1$. Jika $r=-1$ berarti korelasinya negatif, $r=0$ berarti tidak terdapat korelasi, dan $r=1$ berarti korelasi yang terjadi sangat kuat.

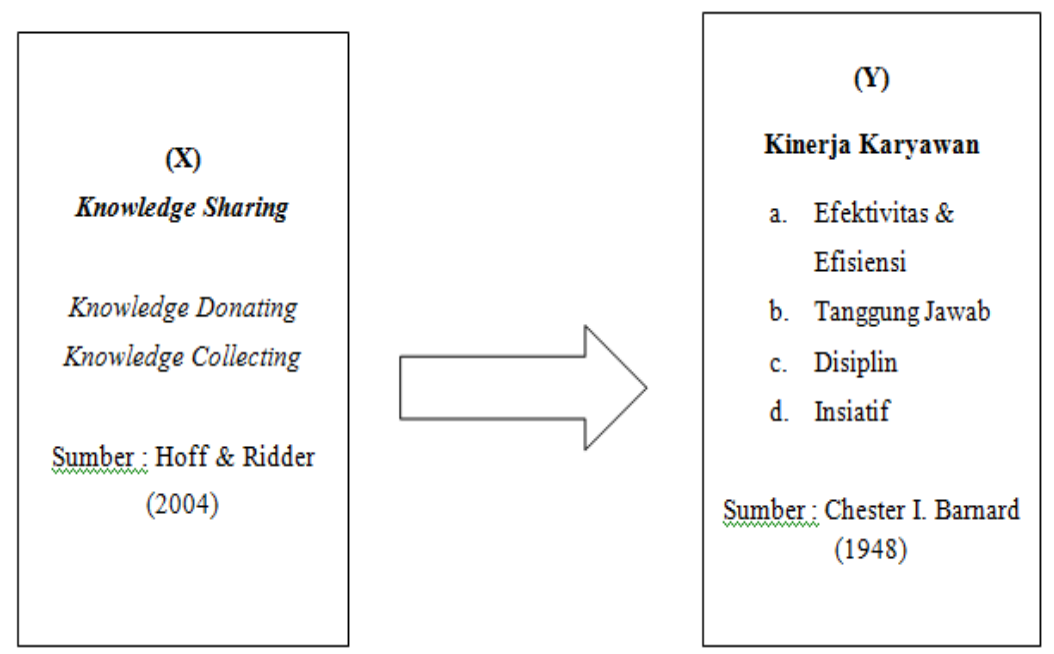

Gambar 1. Kerangka Pemikiran

Analisis Regresif sederhana dilakukan untuk mengetahui pengaruh orientasi pasar terhadap strategi keunggulan bersaing, dengan linier sederhana yang bertujuan untuk meramalkan atau memprediksikan besaran nilai variabel terikat yang dipengaruhi oleh variabel bebas. Berikut ini rumus regresi linier sederhana:

Keterangan:

$$
\mathbf{Y}=\mathbf{a}+\mathbf{b} \cdot \mathbf{X}
$$

$\mathrm{Y}=$ Variabel Terikat

$\mathrm{X}=$ Variabel Bebas

$\mathrm{a}$ dan $\mathrm{b}=$ Konstanta

Koefisien determinasi dapat dihitung dengan mengkuadratkan korelasi yang sebelumnya sudah dihitung kemudian dikali dengan $100 \%$.Nilai koefisiensi determinasi yaitu antara $0-1$.Jika nilai yang dihasilkan kecil, berarti kemampuan variabel bebas dalam mempengaruhi variabel terikat sangat rendah.Sedangkan nilai yang dihasilkan mendekati 1 berarti kemampuan variabel bebas dalam mempengaruhi variabel terikat sangat tinggi. Koesifisien determinasi dapat dinyatakan dalam bentuk sebuah persentase yang sesuai dengan rumus dibawah ini:

$$
\mathrm{Kd}=\mathbf{r} \times 100 \%
$$

Keterangan :

$\mathrm{Kd}=$ Koefisiensi determinasi

$\mathrm{R}=$ Koesifiensi korelasi yang digunakan

Menurut Sugiama (2008), hipotesis merupakan suatu pernyataan berdasarkan dugaan sementara yang diajukan yang kemudian diuji secara empirik. Semakin tinggi tingkat $\alpha$ maka akan semakin rendah tingkat kepercayaannya. Penelitian ini menggunakan tingkat kepercayaan $95 \%$ atau $\geq 0,05$. Jika hasil probabilitas $>0,05$ maka Ho diterima, sedangkan $<0,05$ Ho ditolak. Selain itu, penelitian ini menggunakan koefisien determinasi, Uji - F, dan Uji - t. Uji - F digunakan untuk menunjukkan apakah model yang dihasilkan mempunyai pengaruh secara bersama - sama antara variabel bebas terhadap variabel terikat. Sedangkan untuk Uji - $\mathrm{t}$ digunakan untuk menunjukkan seberapa besar pengaruh yang dihasilkan. Pada uji $-\mathrm{t}$ ini diukur dengan tingkat signifikansi 0,05 . Jika tingkat signifikansi $\mathrm{t}$ hitung $>0,05$ atau $\mathrm{t}$ hitung $<\mathrm{t}$ tabel maka Ho diterima dan jika tingkat signifikansi $\mathrm{t}$ hitung $<0,05$ atau $\mathrm{t}$ hitung $>\mathrm{t}$ tabel maka Ho ditolak. 


\section{Hasil dan Pembahasan}

\subsection{Analisis Deskriptif}

Analisis deskriptif knowledge sharing ini dilakukan untuk menjawab identifikasi masalah yang pertama dalam penelitian ini yaitu bagaimana implementasi knowledge sharing yang diterapkan PT Dirgantara Indonesia (Persero). Berdasarkan pada tabel 4.6, dapat terlihat bahwa nilai mean yang dihasilkan sebesar 4,20 berada pada kategori "Baik", Hal itu dapat mengindikasikan bahwa knowledge sharing yang dilakukan oleh karyawan PT Dirgantara Indonesia (Persero) sudah secara optimal dalam pelaksanaannya.

Tabel 2. Uji Deskriptif Variabel Knowledge Sharing

\begin{tabular}{|l|r|r|r|r|r|}
\hline & \multicolumn{1}{|c|}{$\mathrm{N}$} & Minimum & Maximum & \multicolumn{1}{c|}{ Mean } & Std. Deviation \\
\hline Knowledge Donating & 148 & 2.50 & 5.00 & 3.9645 & .53849 \\
Knowledge Collecting & 148 & 3.00 & 5.00 & 4.4414 & .51466 \\
Knowledge Shaning & 148 & 3.00 & 5.00 & 4.2030 & .44358 \\
Valid N (listwise) & 148 & & & & \\
& & & & & \\
\hline
\end{tabular}

Variabel knowledge sharing memiliki dua dimensi di dalamnya, yaitu dimensi knowledge donating dan dimensi knowledge collecting. Kedua dimensi tersebut memiliki nilai mean yang termasuk kedalam kategori "Baik". Hal itu dapat mengindikasikan bahwa karyawan PT Dirgantara Indonesia (Persero) sudah mengimplementasikan knowledge sharing dengan cara knowledge donating (memberikan informasi) dan knowledge collecting (mengumpulkan informasi) dengan baik. Sehingga dapat disimpulkan bahwa karyawan PT Dirgantara Indonesia (Persero) sudah memiliki budaya knowledge sharing dan sudah mengimplementasikan knowledge sharing dalam perusahaannya.

Terdapat empat pernyataan dari dimensi knowledge donating ini. Keempat pernyataan itu mampu menjelaskan mengenai dimensi ini. Dari empat pernyataan, pernyataan dengan nomor kuesioner 2 mempunyai nilai rata-rata paling tinggi dibanding yang lainnya. Pernyataan tersebut yaitu berbagi informasi dengan rekan kerja, dengan nilai mean sebesar 4,351 dimana termasuk kategori baik. Hal itu dapat menunjukkan bahwa karyawan PT Dirgantara Indonesia (Persero) sudah terbiasa untuk melakukan pembagian informasi terhadap rekan kerjanya seputar pekerjaan yang dilakukan di perusahaan.

Tabel 3. Uji Deskriptif Dimensi Knowledge Donating

\begin{tabular}{|l|r|r|r|r|r|}
\hline & N & Minimum & Maximum & Mean & Std. Deviation \\
\hline X1 & 148 & 2.00 & 5.00 & 4.0676 & .68673 \\
X3 & 148 & 3.00 & 5.00 & 4.3514 & .54542 \\
X4 & 148 & 2.00 & 5.00 & 3.9865 & .74675 \\
Knowledge Donating & 148 & 1.00 & 5.00 & 3.4527 & .95001 \\
Valid N (listwise) & 148 & 2.50 & 5.00 & 3.9645 & .53849 \\
& & & & & \\
\hline
\end{tabular}


Dari hasil penelitian, dapat diambil kesimpulan bahwa knowledge donating yang diterapkan oleh karyawan PT Dirgantara Indonesia sudah terlaksana dengan baik akan tetapi perlu ditingkatkan kembali agar lebih optimal. Hal yang perlu ditingkatkan adalah berbagi informasi mengenai pekerjaan apa yang sedang dilakukan terhadap rekan kerja agar dapat saling mengetahui proses kerja yang berlangsung sesama rekan kerja.

Terdapat tiga pernyataan dari dimensi knowledge collecting ini. Ketiga pernyataan itu mampu menjelaskan mengenai dimensi ini. Dari tiga pernyataan, pernyataan dengan nomor kuesioner 6 mempunyai nilai rata-rata paling tinggi dibanding yang lainnya. Pernyataan tersebut yaitu dimana karyawan akan senang bila rekan kerjanya memberikan pengetahuan atau informasi yang berhubungan dengan pekerjaan, dengan nilai mean sebesar 4,54 dimana termasuk kategori sangat baik. Hal itu dapat menunjukkan bahwa karyawan PT Dirgantara Indonesia (Persero) benar-benar terbuka dalam membutuhkan pengetahuan dan juga informasi yang disebarkan melalui rekan kerjanya untuk mendukung kinerjanya.

Tabel 4. Uji Deskriptif Dimensi Knowledge Collecting

\begin{tabular}{|l|r|r|r|r|r|}
\hline & \multicolumn{1}{|c|}{ N } & Minimum & Maximum & Mean & Std. Deviation \\
\hline X5 & 148 & 3.00 & 5.00 & 4.4797 & .56508 \\
X7 & 148 & 3.00 & 5.00 & 4.5473 & .56345 \\
Knowledge Collecting & 148 & 3.00 & 5.00 & 4.2973 & .70431 \\
Valid N (istwise) & 148 & 3.00 & 5.00 & 4.4414 & .51466 \\
& 148 & & & & \\
\hline
\end{tabular}

Dari hasil penelitian, dapat diambil kesimpulan bahwa knowledge collecting yang diterapkan oleh karyawan PT Dirgantara Indonesia sudah terlaksana dengan sangat baik melihat dari semua pernyataan yang memiliki nilai rata-rata sangat baik, yaitu diatas angka 4,20. Hal ini harus dipertahankan oleh karyawan agar dapat terus mengumpulkan informasi dengan baik di perusahaan.

Tabel 5. Uji Deskriptif Variabel Kinerja Karyawan

\begin{tabular}{|l|r|r|r|r|r|}
\hline & \multicolumn{1}{|c|}{$\mathrm{N}$} & Minimum & Maximum & \multicolumn{1}{c|}{ Mean } & Std. Deviation \\
\hline Efektivitas \& Efisiensi & 148 & 2.60 & 5.00 & 3.9838 & .48079 \\
Tanggung Jawab & 148 & 2.78 & 5.00 & 4.2492 & .42977 \\
Disiplin & 148 & 2.29 & 5.00 & 3.8909 & .57370 \\
Inisiatif & 148 & 2.60 & 5.00 & 3.8574 & .44264 \\
Kualitas Kinerja Karyawan & 148 & 2.92 & 4.94 & 3.9970 & .40430 \\
Valid N (listwise) & 148 & & & & \\
& & & & & \\
\hline
\end{tabular}

Analisis deskriptif kinerja karyawan ini dilakukan untuk menjawab dengan jelas mengenai identifikasi masalah yang kedua dalam penelitian ini yaitu bagaimana kualitas kinerja karyawan PT Dirgantara Indonesia (Persero). Berdasarkan hasil tabel 4.10, dapat terlihat bahwa hasil nilai mean sebesar 3,99 yang berada pada kategori "Baik". Hal ini mengindikasikan bahwa secara keseluruhan kinerja karyawan PT Dirgantara Indonesia (Persero) sudah terlaksana dengan baik. 
Tabel 6. Uji Deskriptif Dimensi Efektivitas \& Efisiensi

\begin{tabular}{|l|r|r|r|r|r|}
\hline & N & Minimum & Maximum & Mean & Std. Deviation \\
\hline Y1 & 148 & 3.00 & 5.00 & 4.1419 & .62825 \\
Y3 & 148 & 2.00 & 5.00 & 3.9932 & .65462 \\
Y4 & 148 & 2.00 & 5.00 & 3.8176 & .67044 \\
Y5 & 148 & 2.00 & 5.00 & 3.4527 & .74079 \\
Y6 & 148 & 3.00 & 5.00 & 4.3851 & .54115 \\
Y7 & 148 & 2.00 & 5.00 & 4.0676 & .72527 \\
Y8 & 148 & 2.00 & 5.00 & 4.0338 & .66410 \\
Y9 & 148 & 2.00 & 5.00 & 3.9865 & .71890 \\
Y10 & 148 & 2.00 & 5.00 & 3.9257 & .70074 \\
Efektivitas \& Efisiensi & 148 & 2.00 & 5.00 & 4.0338 & .64329 \\
Valid N (listwise) & 148 & 2.60 & 5.00 & 3.9838 & .48079 \\
& 148 & & & & \\
\hline
\end{tabular}

Kesepuluh pernyataan itu mampu menjelaskan mengenai dimensi ini. Dari sepuluh pernyataan, pernyataan dengan nomor kuesioner 5 mempunyai nilai rata-rata paling tinggi dibanding yang lainnya. Pernyataan tersebut yaitu dimana berusaha dengan serius menyelesaikan pekerjaan sampai dengan selesai, dengan nilai mean sebesar 4,54 dimana termasuk kategori sangat baik. Hal itu dapat menunjukkan bahwa karyawan PT Dirgantara Indonesia (Persero) benar-benar memanfaatkan waktu yang ada untuk menyelesaikan pekerjaannya hingga tuntas walaupun harus mengorbankan waktu yang dimiliki untuk hal lainnya.

Dari hasil penelitian, dapat diambil kesimpulan bahwa efektivitas \& efisiensi yang diterapkan oleh karyawan PT Dirgantara Indonesia sudah terlaksana dengan baik, namun masih ada hal yang perlu ditingkatkan lagi. Hal yang harus ditingkatkan tersebut adalah dimana karyawan harus lebih akurat dan teliti dalam mengerjakan setiap pekerjaan yang diberikan, dan harus meminimalisir kesalahan yang dilakukan.

Tabel 7. Uji Deskriptif Dimensi Tanggung Jawab

\begin{tabular}{|l|r|r|r|r|r|}
\hline & N & Minimum & Maximum & \multicolumn{1}{l|}{ Mean } & Std. Deviation \\
\hline Y11 & 148 & 3.00 & 5.00 & 4.4595 & .55179 \\
Y12 & 148 & 3.00 & 5.00 & 4.4324 & .54911 \\
Y14 & 148 & 2.00 & 5.00 & 4.3108 & .58148 \\
Y15 & 148 & 3.00 & 5.00 & 4.4595 & .59907 \\
Y16 & 148 & 1.00 & 5.00 & 4.1892 & .66344 \\
Y17 & 148 & 2.00 & 5.00 & 3.9662 & .69415 \\
Y18 & 148 & 2.00 & 5.00 & 4.2838 & .61766 \\
Y19 & 148 & 1.00 & 5.00 & 3.9797 & .58866 \\
Tanggung Jawab & 148 & 3.00 & 5.00 & 4.1622 & .56005 \\
Valid N (listwise) & 148 & 2.78 & 5.00 & 4.2492 & .42977 \\
& 148 & & & & \\
\hline
\end{tabular}

Terdapat sembilan pernyataan dari dimensi tanggung jawab ini. Kesembilan pernyataan itu mampu menjelaskan mengenai dimensi ini. Dari sembilan pernyataan, pernyataan dengan nomor kuesioner 11 dan 14 mempunyai nilai rata-rata paling tinggi dibanding yang lainnya. Pernyataan tersebut yaitu dimana karyawan merasa mempunyai tanggung jawab terhadap pekerjaan yang dibebankan kepadanya dan juga karyawan bersedia bertanggung jawab atas hasil kerja yang dicapai, dengan nilai mean sebesar 4,59 dimana termasuk kategori sangat baik. Hal itu dapat menunjukkan bahwa karyawan PT 
Dirgantara Indonesia (Persero) sudah memiliki kesadaran akan tanggung jawab yang diembannya di dalam pekerjaanya, dan lebih memperhatikan pekerjaannya.

Dari hasil penelitian, dapat diambil kesimpulan bahwa tanggung jawab yang diterapkan oleh karyawan PT Dirgantara Indonesia sudah terlaksana dengan sangat baik melihat mayoritas pernyataan yang memiliki nilai rata-rata sangat baik, yaitu diatas angka 4,20. Hal ini harus dipertahankan oleh karyawan.

Tabel 8. Uji Deskriptif Dimensi Disiplin

\begin{tabular}{|l|r|r|r|r|r|}
\hline & N & Minimum & Maximum & Mean & Std. Deviation \\
\hline Y20 & 148 & 2.00 & 5.00 & 4.0946 & .71274 \\
Y21 & 148 & 1.00 & 5.00 & 3.6824 & .90379 \\
Y22 & 148 & 2.00 & 5.00 & 3.8378 & .84156 \\
Y23 & 148 & 1.00 & 5.00 & 3.6757 & .82657 \\
Y24 & 148 & 2.00 & 5.00 & 3.9595 & .67892 \\
Y25 & 148 & 2.00 & 5.00 & 3.9932 & .72372 \\
Y26 & 148 & 2.00 & 5.00 & 3.9932 & .67508 \\
Disiplin & 148 & 2.29 & 5.00 & 3.8909 & .57370 \\
Valid N (isttwise) & 148 & & & & \\
\hline
\end{tabular}

Terdapat tujuh pernyataan dari dimensi tanggung jawab ini. Ketujuh pernyataan itu mampu menjelaskan mengenai dimensi ini. Dari tujuh pernyataan, pernyataan dengan nomor kuesioner 20 mempunyai nilai rata-rata paling tinggi dibanding yang lainnya. Pernyataan tersebut yaitu dimana kedisiplinan karyawan dapat diterapkan dalam menyelesaikan pekerjaan, dengan nilai mean sebesar 4,09 dimana termasuk kategori baik. Hal itu dapat menunjukkan bahwa karyawan di PT Dirgantara Indonesia (Persero) sudah merasa memiliki kedisiplinan di dalam dirinya masing-masing yang dapat diterapkan di dalam pekerjaannya sehari-hari.

Dari hasil penelitian, dapat diambil kesimpulan bahwa disiplin yang diterapkan oleh karyawan di PT Dirgantara Indonesia sudah terlaksana dengan baik melihat setiap pernyataan yang memiliki nilai rata-rata yang tergolong ke dalam penilaian baik, hanya saja terdapat hal yang perlu ditingkatkan lagi. Hal yang harus ditingkatkan oleh karyawan adalah mengenai masalah ketepatan waktu dalam kehadiran setiap harinya, dan juga harus bisa lebih meminimalisir pelanggaran yang dilakukan terhadap perintah yang diberikan oleh atasan.

Tabel 9. Uji Deskriptif Dimensi Inisiatif

\begin{tabular}{|l|r|r|r|r|r|}
\hline & N & Minimum & Maximum & Mean & Std. Deviation \\
\hline Y27 & 148 & 2.00 & 5.00 & 3.9595 & .68887 \\
Y28 & 148 & 1.00 & 5.00 & 4.0270 & .68953 \\
Y30 & 148 & 2.00 & 5.00 & 3.9189 & .62285 \\
Y31 & 148 & 1.00 & 5.00 & 3.7770 & .74524 \\
Y32 & 148 & 2.00 & 5.00 & 3.4189 & .79977 \\
Y33 & 148 & 1.00 & 5.00 & 3.6014 & .86299 \\
Y34 & 148 & 2.00 & 5.00 & 4.0946 & .62093 \\
Y35 & 148 & 1.00 & 5.00 & 3.8986 & .58017 \\
Y36 & 148 & 2.00 & 5.00 & 3.8784 & .55825 \\
Inisiatif & 148 & 1.00 & 5.00 & 4.0000 & .63888 \\
Valid N (listwise) & 148 & 2.60 & 5.00 & 3.8574 & .44264 \\
& 148 & & & & \\
\hline
\end{tabular}


Terdapat sepuluh pernyataan dari dimensi inisiatif ini. Kesepuluh pernyataan itu mampu menjelaskan mengenai dimensi ini. Dari sepuluh pernyataan, pernyataan dengan nomor kuesioner 33 mempunyai nilai rata-rata paling tinggi dibanding yang lainnya. Pernyataan tersebut yaitu dimana karyawan bersedia memperbaiki kesalahan tanpa harus diperintah oleh atasan, dengan nilai mean sebesar 4,09 dimana termasuk kategori baik. Hal itu dapat menunjukkan bahwa karyawan di PT Dirgantara Indonesia (Persero) sudah memiliki kesadaran untuk memperbaiki kesalahannya tanpa harus ditegur ataupun diperintah oleh atasannya, tetapi berinisiatif untuk melakukannya atas kesadaran sendiri.

Dari hasil penelitian, dapat diambil kesimpulan bahwa inisiatif yang diterapkan oleh karyawan di PT Dirgantara Indonesia sudah terlaksana dengan baik melihat setiap pernyataan yang memiliki nilai rata-rata yang tergolong ke dalam penilaian baik, hanya saja terdapat hal yang perlu ditingkatkan lagi. Hal yang harus ditingkatkan oleh karyawan adalah keberanian dan inisiatif untuk mencoba cara-cara baru untuk dapat menyelesaikan pekerjaannya dengan lebih baik, tidak hanya terpaku pada cara yang sama-sama saja.

\section{Kesimpulan}

Dari hasil penelitian yang dilakukan oleh peneliti mengenai pengaruh knowledge sharing terhadap kinerja karyawan, dapat ditarik kesimpulan sebagai berikut:

1. Knowledge sharing yang diterapkan karyawan pada perusahaan milik pemerintah seperti PT Dirgantara Indonesia (Persero) sudah baik. Hal ini terlihat dari nilai mean dari variabel knowledge sharing yang diujikan pada karyawan berada pada kategori tinggi. Dari kedua dimensi yang ada, dimensi knowledge collecting memiliki nilai mean lebih tinggi daripada dimensi knowledge donating yang memiliki nilai mean lebih rendah. Hal ini mengindikasikan bahwa karyawan dalam penerapan knowledge sharing di pekerjaannya, lebih cenderung aktif dalam menanyakan informasi seputar pekerjaan kepada rekan kerjanya dibandingkan dengan inisiatif langsung untuk memberikan dan membagikan informasi kepada rekan kerjanya.

2. Kinerja karyawan yang terdapat pada karyawan sudah baik. Hal ini terlihat dari nilai mean yang berada di dalam kategori "Tinggi" yang dilihat pengukurannya dari keempat dimensi yang ada, yaitu efektivitas \& efisiensi, tanggung jawab, disiplin, dan juga inisiatif. Inisiatif merupakan dimensi yang memiliki nilai mean yang paling rendah yang terdapat di dalam variabel kinerja karyawan. Sedangkan tanggung jawab merupakan dimensi dengan nilai mean tertinggi yang terdapat di dalam variabel kinerja karyawan.

3. Terdapat hubungan yang positif serta signifikan antara knowledge sharing dengan kinerja karyawan. Selain itu, knowledge sharing sendiri mempunyai pengaruh sebesar 10,6\% terhadap kualitas kinerja karyawan dan sisanya sebesar 89,6\% dipengaruhi oleh faktor lainnya yang tidak dijelaskan di dalam penelitian ini.

\section{Daftar Pustaka}

Asegaff, M. \& Wasitowati. (2015). Knowledge Sharing Sebagai Sumber Inovasi dan Keunggulan Bersaing Pada Usaha Mikro Kecil dan Menengah (UMKM) Sektor Batik. Jurnal UNISSULA Teknik Ekonomi, 2(1), $208-221$.

Aulia, A. (2016). Pengaruh Budaya Organisasi Terhadap Kinerja Karyawan Melalui Knowledge Sharing Sebagai Variabel Intervening (Studi Pada PT. Pelabuhan Indonesia III Cabang Tanjung Perak Surabaya). Jurnal Ilmu Manajemen, 4 (3), 1-15.

Azadehdel, M. R. \& Jamshidinejad, M. A. (2015). The Relationship between Knowledge Sharing, Innovation, and Performance. Interdisciplinary Journal Of Contemporary Research In Business, 5 (5), $408-412$.

Barnard, C. I. (1948). Organization and Management: Selected Papers. Cambridge, MA: Harvard University Press.

Ghozali, I. (2011). Aplikasi Analisis Multivariate Dengan Program IBM SPSS 19 (edisi kelima). Semarang : Universitas Diponegoro.

Indrawati. (2015). Metode Penelitian Manajemen dan Bisnis Konvergensi Teknologi Komunikasi dan Informasi. Bandung : Aditama.

Mangkunegara, A. P. (2010). Evaluasi Kinerja SDM. Jakarta : Refika Aditama. 
Noor, J. (2014). Metodologi Penelitian. Jakarta : Kencana.

Notoatmodjo, S. (2010). Metode Penelitian Kesehatan, Edisi Revisi. Jakarta : Rineka Cipta.

Ruky. (2010). Organisasi dan Motivasi Dasar Peningkatan Produktivitas. Jakarta : PT Bumi Aksara.

Simanjuntak, P. J. (2011). Manajemen Evaluasi Kinerja. Jakarta : Lembaga Penerbit Fakultas Ekonomi Universitas Indonesia.

Sinambela, L. P. (2012). Kinerja Pegawai: Teori Pengukuran dan Implikasi. Yogyakarta : Graha Ilmu. Sugiama, A. G. (2008). Metode Riset Bisnis dan Manajemen. Bandung : Guardaya Intimarta.

Sugiyono. (2013). Metode Penelitian Kuantitatif Kualitatif dan $R \&$ D. Bandung : Alfabeta.

Sunyoto, A. (2010). Adobe Flash + XML = Rich Multimedia Application. Yogyakarta : Andi Offset.

Tobing, P. L. (2011). Manajemen Knowledge Sharing Berbasis Komunitas. Bandung : Graha Ilmu.

Wening, N. \& Harsono, M. (2016). Relationship between knowledge sharing to individual Performance. International Journal of Research in Business Management, 4 (1), 67 - 78.

Wibowo. (2011). Manajemen Kinerja. Jakarta : Rajawali Pers.

*Email korespondensi:

stephenandreas62@gmail.com 